\title{
A Study Aimed at Assessing Antenatal Maternal Knowledge of Janani Suraksha Yojana
}

\author{
Sweety Sanju \\ Holy Family Institute of Nursing Education, Kurla west, Mumbai, India
}

\begin{abstract}
Easy Accessibility to health care service is important safe motherhood and reducing maternal and neo natal mortality. The objective of the study was to assess the knowledge of antenatal mothers regarding Janani Suraksha Yojana. This descriptive study was conducted on a sample size of forty women from different sections of the society. The results indicate that nearly $80 \%$ of the people lack a proper knowledge of the Janani Suraksha Yojana and steps need to be taken to increase awareness among people, especially mothers, about it.
\end{abstract}

Key words: Janani Suraksha Yojana, Antenatal mothers.

\section{Introduction}

Safe motherhood is perceived as a human right and the health sector is always encouraged to provide quality services to ensure the same. JananiSuraksha Yojana is a safe motherhood intervention scheme under the National Rural Health Mission being implemented with the objectives of reducing maternal and neo-natal mortality by promoting institutional delivery among the poor pregnant women. The Janani Suraksha Yojana is a centrally sponsored scheme of Government of India was launched on $12^{\text {th }}$ April 2005 by the Honorable Prime minister of India. The scheme is implemented in all states with special focus on low performing states with high rate of maternal and neo natal mortality.

A community based cross sectional study was conducted from January 2009 to December 2009 among 3212 women to explore the reasons of missed opportunities of Janani Suraksha Yojana benefits among the beneficiaries of Solapur slum area. Out of total sample size $11.20 \%$ were eligible for getting the benefit of Janani Suraksha Yojana. Of that only $32.78 \%$ women got the benefit of Janani Suraksha Yojana while, $67.22 \%$ missed the opportunity of getting Janani Suraksha Yojana benefit due to lack of awareness.

\subsection{Statement of the problem}

"A study to assess the knowledge level of antenatal mothers regarding Janani Suraksha Yojana in a selected Hospital in Mumbai, with a view to develop information booklet"

\subsection{Objectives}

1) To assess the knowledge level of antenatal mothers regarding Janani Suraksha Yojana
2) To determine the association between the selected demographic variables and knowledge level of Antenatal mothers regarding Janani Suraksha Yojana

3) To prepare an information booklet on Janani suraksha Yojana

\section{Methods and Material}

Non probability purposive sampling technique is used and data was collected from 40 antenatal mothers visiting Gynaec OPD of a Hospital, Mumbai. Adequate information regarding the purpose of the study was provided and consent was obtained. The demographic data was collected followed by questionnaires, given to assess their knowledge regarding Janani Suraksha Yojana. At the end, information booklets were being provided to the antenatal mothers.

\section{Results and Discussion}

Findings related to primi mothers knowledge regarding Janani suraksha Yojana

Table 1: Mean, standard deviation and overall knowledge score on Janani Suraksha Yojana, N=40

\begin{tabular}{c|c|c|c|c|}
$\begin{array}{c}\text { Total } \\
\text { sample }\end{array}$ & $\begin{array}{c}\text { No. of } \\
\text { Question }\end{array}$ & Mean & $\begin{array}{c}\text { Standard } \\
\text { deviation }\end{array}$ & $\begin{array}{c}\text { Mean } \\
\text { percentage }\end{array}$ \\
\hline 40 & 25 & 58.59 & 23.71 & $49.4 \%$ \\
\hline
\end{tabular}

Table 2: Distribution of sample with reference to level of knowledge, $\mathrm{N}=40$

Level of knowledge \% of score Frequency Frequency percentage

\begin{tabular}{|c|c|c|c|}
\hline Very poor & $0-25$ & 3 & $7.5 \%$ \\
\hline Poor & 2650 & 11 & $27.5 \%$ \\
\hline Good & $51-75$ & 18 & $45 \%$ \\
\hline Very good & $76-100$ & 6 & $15 \%$ \\
\hline Excellent & 101125 & 2 & $5 \%$ \\
\hline
\end{tabular}


Table 3: Findings related to association between the knowledge regarding Janani suraksha Yojana, N=40

\begin{tabular}{|c|c|c|c|c|c|c|c|c|c|c|}
\hline \multirow[b]{2}{*}{ Sr No } & \multirow[b]{2}{*}{ Demographic Variables } & \multicolumn{9}{|c|}{ Knowledge Score } \\
\hline & & $\begin{array}{c}\text { Very Poor } \\
0-25\end{array}$ & $\begin{array}{l}\text { Poor } \\
26-50\end{array}$ & $\begin{array}{l}\text { Good } \\
51-75\end{array}$ & $\begin{array}{c}\text { Very Good } \\
76-100\end{array}$ & \begin{tabular}{|c|} 
Excellent \\
$101-125$ \\
\end{tabular} & $\begin{array}{l}\text { Calculated value } \\
\text { (chi-square) }\end{array}$ & df & $\begin{array}{l}\text { Table } \\
\text { value }\end{array}$ & P-value \\
\hline 1. & AGE & & & & & & \multirow{4}{*}{30.716} & \multirow{4}{*}{8} & \multirow{4}{*}{15.51} & \multirow{4}{*}{$0.5 \mathrm{~S}$} \\
\hline & $*<25$ years & 0 & 3 & 2 & 0 & 0 & & & & \\
\hline & *25-30years & 1 & 5 & 14 & 6 & 1 & & & & \\
\hline & $*>30$ years & 2 & 2 & 2 & 1 & 1 & & & & \\
\hline \multirow[t]{5}{*}{2.} & Educational status & & & & & & \multirow{5}{*}{18.547} & \multirow{5}{*}{12} & \multirow{5}{*}{21.03} & \multirow{5}{*}{$\begin{array}{l}0.5 \\
\text { NS }\end{array}$} \\
\hline & $* \mathrm{Up}$ to $10^{\text {th }}$ & 1 & 5 & 1 & 1 & 1 & & & & \\
\hline & *HSC & 2 & 3 & 8 & 3 & 0 & & & & \\
\hline & *Graduate & 0 & 0 & 6 & 0 & 1 & & & & \\
\hline & *Post graduate & 0 & 2 & 3 & 3 & 0 & & & & \\
\hline \multirow[t]{3}{*}{3.} & Occupation & & & & & & \multirow{3}{*}{3.1} & \multirow{3}{*}{5} & \multirow{3}{*}{11.07} & \multirow{3}{*}{$\begin{array}{l}0.5 \\
\text { NS }\end{array}$} \\
\hline & *House wife & 3 & 7 & 11 & 4 & 2 & & & & \\
\hline & *Employed & 0 & 3 & 7 & 3 & 0 & & & & \\
\hline \multirow[t]{5}{*}{4.} & No. of pregnancy & & & & & & \multirow{5}{*}{19.831} & \multirow{5}{*}{12} & \multirow{5}{*}{21.03} & \multirow{5}{*}{$\begin{array}{l}0.5 \\
\text { NS }\end{array}$} \\
\hline & *First & 1 & 5 & 11 & 3 & 0 & & & & \\
\hline & *Second & 1 & 4 & 7 & 2 & 2 & & & & \\
\hline & *Third & 0 & 0 & 0 & 2 & 0 & & & & \\
\hline & *Fourth and above & 1 & 1 & 0 & 0 & 0 & & & & \\
\hline \multirow[t]{4}{*}{5.} & Religion & & & & & & \multirow{4}{*}{10.05} & \multirow{4}{*}{8} & \multirow{4}{*}{15.51} & \multirow{4}{*}{$\begin{array}{l}0.5 \\
\text { NS }\end{array}$} \\
\hline & *Hindu & 1 & 7 & 12 & 4 & 0 & & & & \\
\hline & *Muslim & 1 & 1 & 0 & 1 & 1 & & & & \\
\hline & $*$ Christian & 1 & 2 & 6 & 2 & 1 & & & & \\
\hline
\end{tabular}

$\mathbf{S}=$ Significant association between knowledge and demographic variables.

NS= Non- Significant association between knowledge and demographic variables.

\section{Conclusion}

Among the demographic variables only age factor of the antenatal mothers had significant association with the knowledge level on Janani Suraksha Yojana. The other demographic factors i.e. educational status, occupation, number of pregnancy and religion did not have any significant association with knowledge level.

\section{Recommendations}

The study can be replicated using a large sample and thereby findings can be generalized in a better way.

\section{References}

[1] Mamatha K.G ,Uma H R ,A Study of Janani suraksha yojana .lambert academic publishing 2013:101-34

[2] Vinayakumari.T,Shantkumari. http. //www. Encyclopedia.com/doc/1G2-3497700412.htm

[3] Neelan Kamari, Shivani Sharma Dr Preeti Gupta, a text book of Midwifery and Gynecological Nursing Pee vee. Multicolor, update edition 2016:260-264

[4] Ministry of Health and Family welfare: JSY guide lines for implementation, Government of India.

[5] Government of India, National Rural Health Mission, Ministry of health and family welfare nirman bhava, New Delhi 2006 